\title{
Radical Induced Fragmentation of Amino Acid Esters Using Triphenylcorrole(CuIII) Complexes
}

\author{
Chagit Denekamp and Emilia Rabkin \\ Department of Chemistry and Institute of Catalysis Science and Technology, Technion - Israel Institute \\ of Technology, Haifa, Israel
}

\begin{abstract}
A triphenylcorrole(CuIII) complex is covalently bound to amino acid esters at the nitrogen atom. As a result radical anions are generated, inducing the occurrence of side-chain reactions under CID conditions. Almost all of the amino acid esters that were studied show abundant ions that correspond to fragmentation at the alpha carbon either with or without the loss of the alkoxy ester moiety. Distinctive CID spectra were also recorded for leucine and isoleucine complexes. Initial results with short peptides are also shown. (J Am Soc Mass Spectrom 2007, 18, 791-801) (c) 2007 American Society for Mass Spectrometry
\end{abstract}

$\mathrm{M}$ ass spectrometry is widely used for the identification and sequencing of peptides that are produced by enzymatic proteolysis of proteins [1-6]. Currently, there are two approaches for the mass spectrometry analysis of proteins, bottom-up and top-down [7]. "Bottom up" strategies to proteome analysis involve cleaving the protein into peptide fragments that are analyzed by electrospray ionization (ESI) or matrix-assisted laser desorption/ionization (MALDI) and collision induced dissociation (CID). In the "topdown" approach, intact protein ions are introduced into the gas phase by ESI and are subsequently fragmented in the mass spectrometer, yielding the molecular masses of both the protein and the fragment ions. If a sufficient number of informative fragment ions are observed, it can provide a complete description of the primary structure of the protein. In any case this CID spectrum can be used as "finger print" for comparison to a database.

Sequencing of peptides is achieved by CID of the charged peptides or electron capture dissociation (ECD) [8] of multiply charged species. For good identification it is desirable to obtain a simple, yet informative MS/MS spectrum of the charged peptide. Primary structure determination necessitates the cleavage of bonds between all amino acid residues. However, since the fragmentation of protonated peptides results in six types of possible fragments, the obtained spectra are sometimes too complicated for sequencing [9]. Charge derivatization of the peptide by a localized charge on either the $\mathrm{N}$ - or $\mathrm{C}$-terminus limits the fragmentation

Published online March 2, 2007

Address reprint requests to Dr. Chagit Denekamp, Department of Chemistry, Technion - Israel Institute of Technology, Haifa 32000, Israel. E-mail: chchagit@tx.technion.ac.il process to charge remote mechanisms, improves the sensitivity, allows the distinction between $\mathrm{N}$ - and $\mathrm{C}$ terminal fragment ions, and simplifies the resulting MS spectrum [10]. Another limitation of the CID method, for closed-shell ions, involves the distinction between structural isomers (e.g., leucine and isoleucine) or similar molecular weight amino acid residues (e.g., glutamine and lysine). Hence, fragmentation of the side chains is required in addition to primary backbone cleavages [11, 12]. Electron capture is a practical technique for generation of peptide radicals. Fragmentation patterns arising from collisional activation of peptide radicals generated through ECD were investigated by several research groups [13-15]. ECD typically cleaves more backbone sites than collisional activation of closed shell ions, resulting in more complete coverage of a peptide sequence $[8,16]$. Product ions are typically $c$ and $z$ fragments, rather than the $b$ and $y$ fragments most commonly seen in the CID of even-electron protonated peptides. Electron capture of peptides and proteins also results in cleavages within amino acid side chains. Cooper et al. showed that side-chain cleavages, resulting in small losses from reduced peptide species, were observed for arginine, histidine, asparagine/glutamine, methionine, and lysine residues [17]. Using hot electron capture dissociation (HECD), multiply protonated polypeptide fragments allow one to distinguish between the isomeric Ile and Leu residues [18, 19]. Nevertheless, ECD is limited to specific instruments.

Another approach that leads to the initiation of homolytic reactions employs the collisional activation of peptide radicals that are generated by the dissociation of transition-metal-peptide complexes [20-23]. One of the first examples was presented by Siu and coworkers who showed that the ternary complex [CuII(dien)(YGGFLR) $]^{2+}$ produces a cationic peptide radical 
<smiles>C1=CC(=C(c2ccccc2)c2ccc(-c3ccc(C(c4ccccc4)=c4ccc(=C(c5ccccc5)c5ccccc5)[nH]4)[nH]3)[nH]2)N=1</smiles>

1

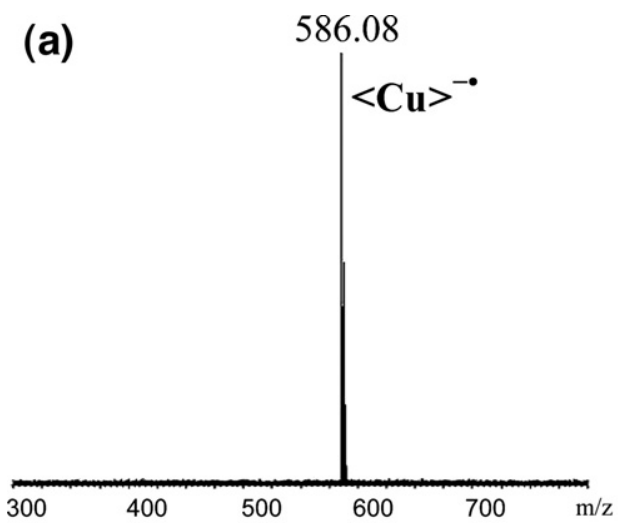

(b)

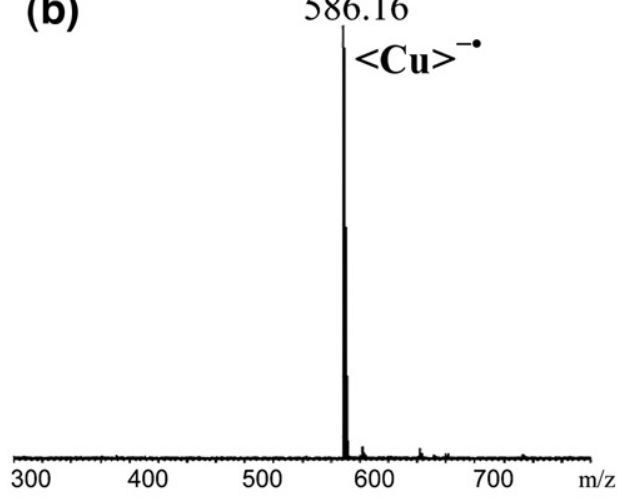

[22]. Gas-phase complexes in which the ligand and the peptide are coordinated to $\mathrm{Cu}(\mathrm{II})$ show some dissociation reactions triggered by elimination of $\mathrm{CO}_{2}$, which is followed by radical-like fragmentations of the amino acid side chain [24-29]. Other studies of metal-peptide interactions show $\mathrm{CO}_{2}$ and/or side-chain loss with different metals like cobalt, nickel, manganese, and others [30]. Various transition metals were shown to induce informative fragmentation of their ligands, giving rise to products, some of which are radicals [31]. Recently, O'Hair and coworkers demonstrated the formation of cationic peptide radicals with trivalent chromium, manganese, iron, and cobalt salen complexes [32]. While the previous examples demonstrate the use

(c)
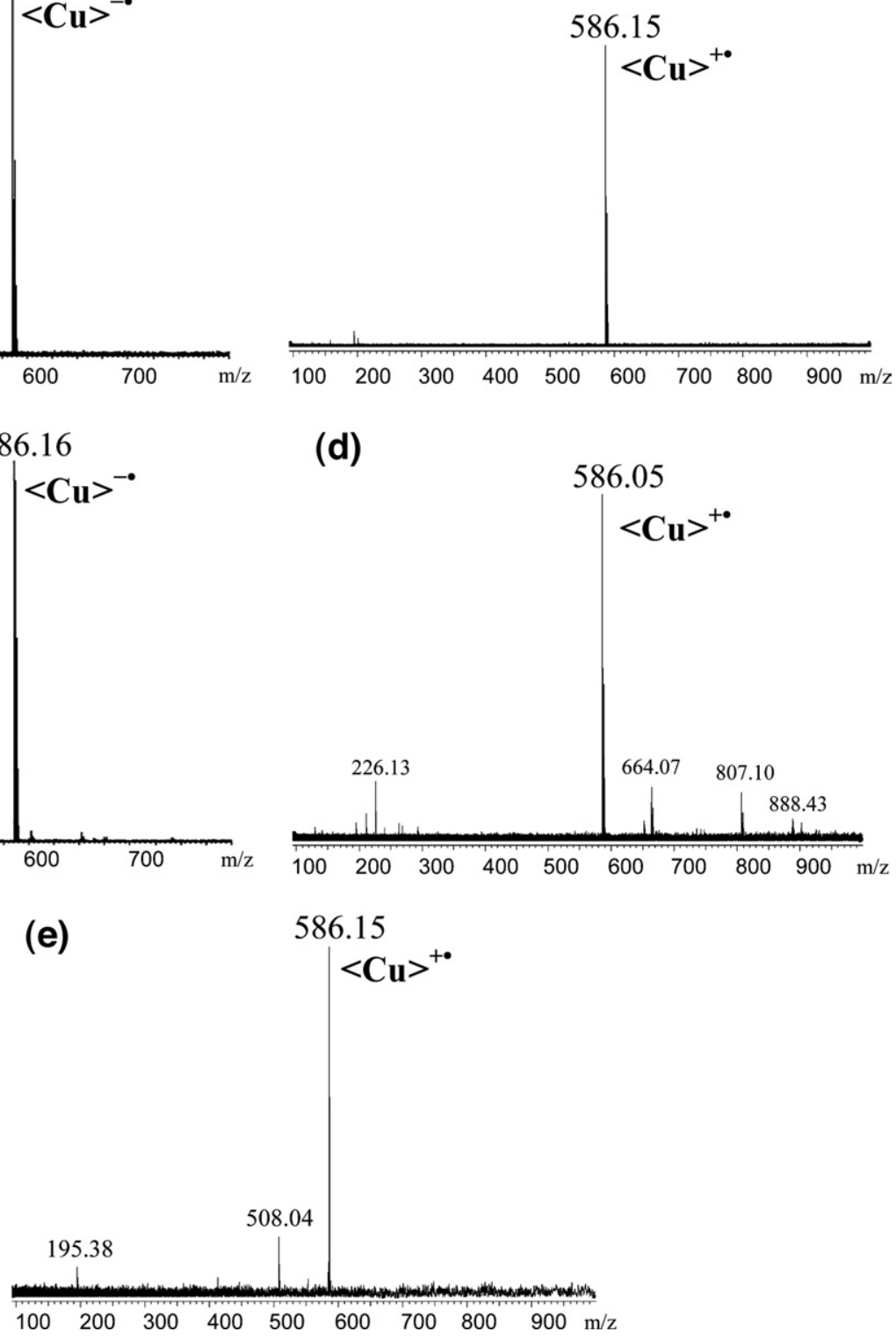

Figure 1. Mass spectra that were measured for the copper complex with (a) MALDI, negative mode, (b) MALDI, positive mode, (c) ESI, negative mode, (d) ESI, positive mode, (e) CID of $<\mathrm{Cu}>^{+ \text {. }}$ (FT-ICR). 


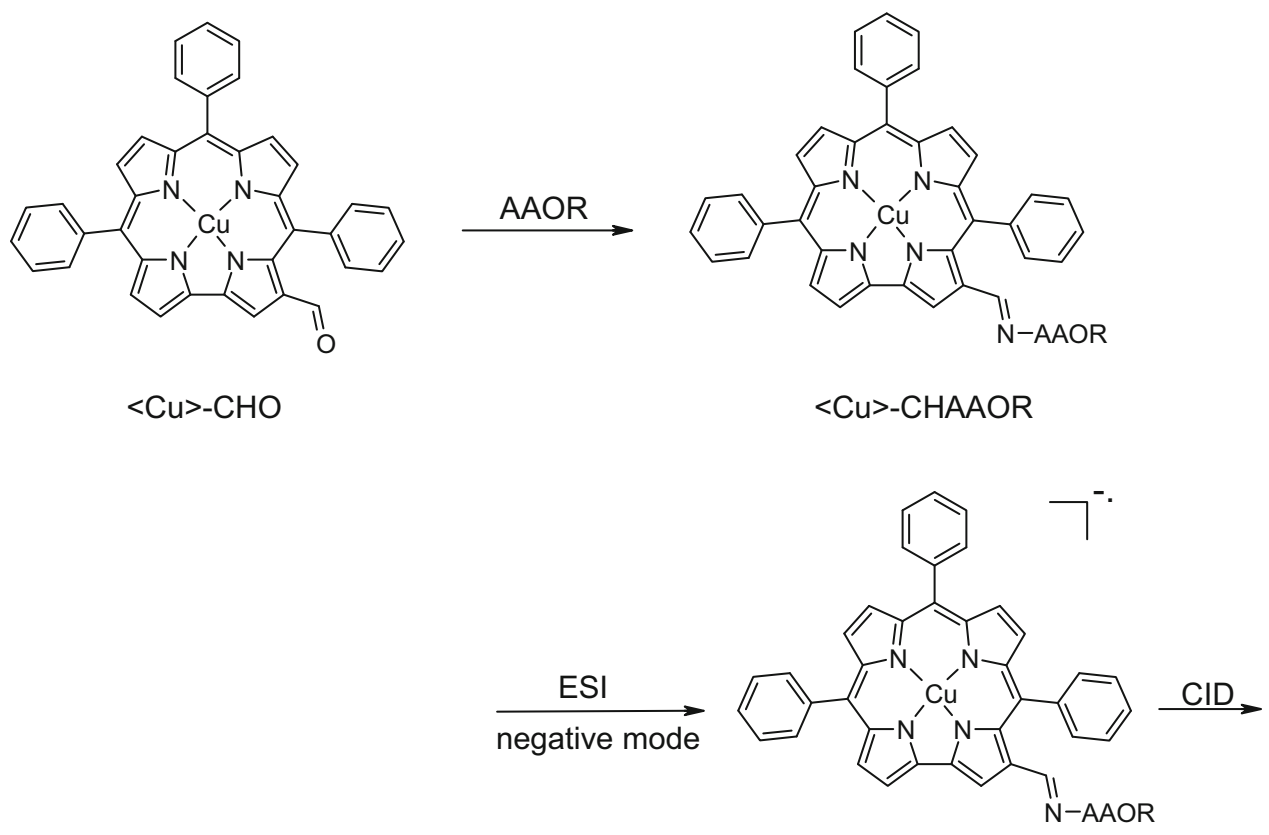

Scheme 1. Charge derivatization of amino acid esters by a $<\mathrm{Cu}>\mathrm{CHO}$ complex and generation of anion radicals from derivatized amino acid esters $<\mathrm{Cu}>$ AAOR.

of organometallic complexes in which the amino acid or peptide interact with the metal as ligands, covalent derivatization of the $\mathrm{N}$-terminal with a ruthenium(II) complex has also been reported [33,34]. This elegant approach proved successful in generating radicals [a $\mathrm{Ru}(\mathrm{I})$ complex is generated upon ionization], the radical cation is formed during the ionization either by MALDI or by ESI. However, the isotopic pattern of Ru complicated the resulting spectra. More recently, Beauchamp and coworkers showed the backbone cleavages for an angiotensin II-Vazo 68 conjugate, with the involvement of radical processes [35]. Nevertheless, in all of the reported examples the relative abundances of fragments produced by side-chain cleavages were rather low and required spectrum enhancement.

Due to their special redox properties, metallocorroles are excellent candidates as open-shell ligands for peptides. Corroles are ring-contracted porphyrin analogues that lack one meso carbon compared with porphyrins and are the fully aromatic versions of corrins. The chemistry of corroles is of great interest since the trinegative corrole ligand significantly sta-

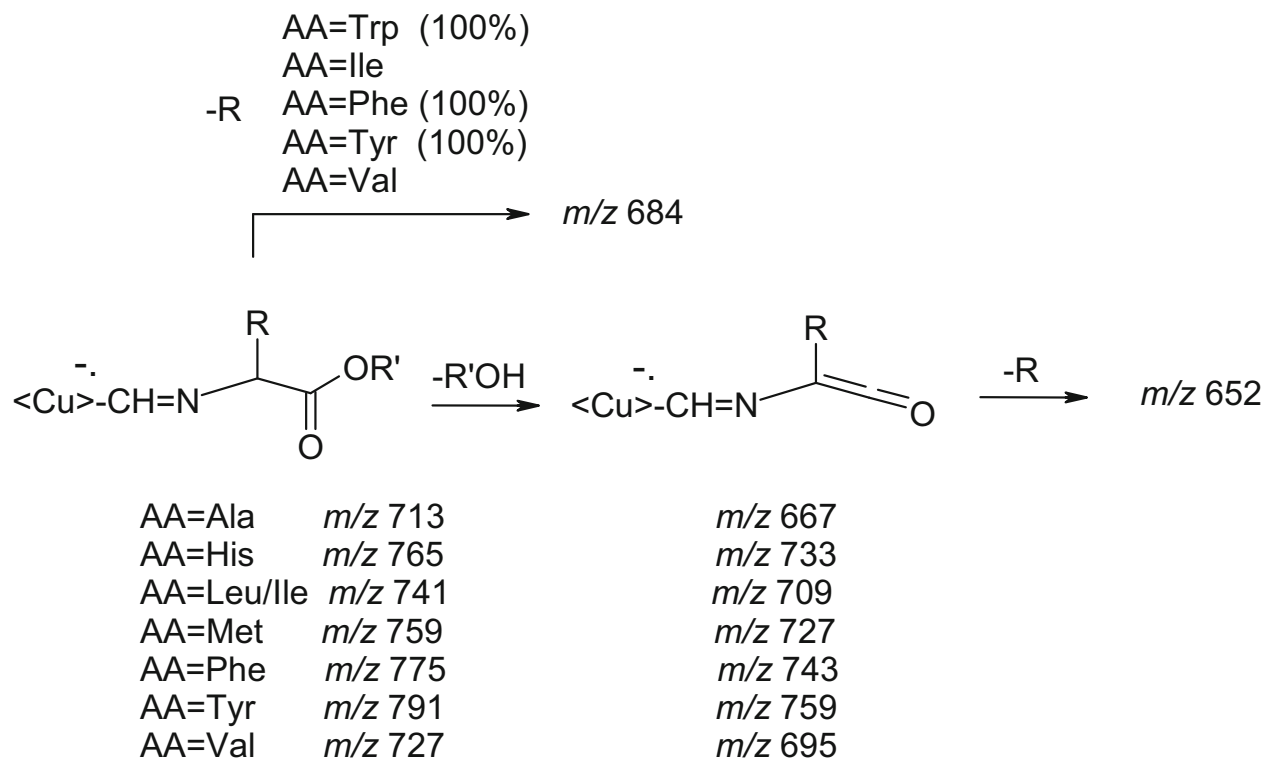

Scheme 2. Side chain homolytic cleavages with or without the initial loss of $\mathrm{ROH}$ from the ester group. 
Table 1. Summary and interpretation of fragments, generated by $\mathrm{CID}$ of $[(\mathrm{Cu}) \mathrm{AlaOEt}]^{-\cdot}[(\mathrm{Cu}) \mathrm{ValOMe}]^{-},[(\mathrm{Cu}) \mathrm{IleOMe}]^{- \text {. }}$ and $[(\mathrm{Cu}) \mathrm{LeuOMe}]^{-}$

\begin{tabular}{|c|c|c|c|c|}
\hline Amino acid & Ala-OEt & Val-OMe & Ile-OMe & Leu-OMe \\
\hline$<\mathrm{Cu}(\mathrm{II})>$ & $\begin{array}{l}\mathrm{R}=\mathrm{CH}_{3} \\
\mathrm{R}^{\prime}=\mathrm{Et} \\
m / z 713 \\
\mathrm{RA}=100 \%\end{array}$ & $\begin{array}{l}\mathrm{R}=\mathrm{CH}\left(\mathrm{CH}_{3}\right)_{2} \\
\mathrm{R}^{\prime}=\mathrm{CH}_{3} \\
m / z 727 \\
\mathrm{RA}=15 \%\end{array}$ & $\begin{array}{l}\mathrm{R}=\mathrm{CH}\left(\mathrm{CH}_{3}\right) \mathrm{CH}_{2} \mathrm{CH}_{3} \\
\mathrm{R}^{\prime}=\mathrm{CH}_{3} \\
m / z 741 \\
\mathrm{RA}=58 \%\end{array}$ & $\begin{array}{l}\mathrm{R}=\mathrm{CH}_{2} \mathrm{CH}\left(\mathrm{CH}_{3}\right)_{2} \\
\mathrm{R}^{\prime}=\mathrm{CH}_{3} \\
m / z 741 \\
\mathrm{RA}=8 \%\end{array}$ \\
\hline & $\begin{array}{l}\mathrm{R}=\mathrm{CH}_{3} \\
m / z 667(-46) \\
\mathrm{RA}=35 \%\end{array}$ & $\begin{array}{l}\mathrm{R}=\mathrm{CH}\left(\mathrm{CH}_{3}\right)_{2} \\
m / z 695(-32) \\
\mathrm{RA}=18 \%\end{array}$ & $\begin{array}{l}\mathrm{R}=\mathrm{CH}\left(\mathrm{CH}_{3}\right) \mathrm{CH}_{2} \mathrm{CH}_{3} \\
m / z 709(-32) \\
\mathrm{RA}=18 \%\end{array}$ & $\begin{array}{l}\mathrm{R}=\mathrm{CH}_{2} \mathrm{CH}\left(\mathrm{CH}_{3}\right)_{2} \\
m / z 709(-32) \\
\mathrm{RA}=10 \%\end{array}$ \\
\hline & - & $\begin{array}{l}\mathrm{R}^{\prime}=\mathrm{CH}_{3} \\
m / z 684(-43) \\
\mathrm{RA}=7 \%\end{array}$ & $\begin{array}{l}\mathrm{R}^{\prime}=\mathrm{CH}_{3} \\
m / z 684(-57) \\
\mathrm{RA}=7 \%\end{array}$ & - \\
\hline & $\begin{array}{l}m / z 652(-61) \\
R A=50 \%\end{array}$ & $\begin{array}{l}m / z 652(-75) \\
R A=28 \%\end{array}$ & $\begin{array}{l}m / z 652(-89) \\
R A=29 \%\end{array}$ & $\begin{array}{l}m / z 652(-89) \\
\mathrm{RA}=28 \%\end{array}$ \\
\hline$<\mathrm{Cu}(\mathrm{II})>$ & $\begin{array}{l}\mathrm{R}=\mathrm{CH}_{3} \\
641(-72) \\
\mathrm{RA}=19 \%\end{array}$ & - & - & - \\
\hline$<\mathrm{Cu}(\mathrm{II})>$ & $\begin{array}{l}\mathrm{R}=\mathrm{CH}_{2} \\
m / z 639(-74) \\
\mathrm{RA}=23 \%\end{array}$ & $\begin{array}{l}\mathrm{R}=\mathrm{C}\left(\mathrm{CH}_{3}\right)_{2} \\
m / z 667(-60) \\
\mathrm{RA}=6 \%\end{array}$ & $\begin{array}{l}\mathrm{R}=\mathrm{C}\left(\mathrm{CH}_{3}\right) \mathrm{CH}_{2} \mathrm{CH}_{3} \\
m / z 681(-60) \\
\mathrm{RA}=6 \%\end{array}$ & $\begin{array}{l}\mathrm{R}=\mathrm{CHCH}\left(\mathrm{CH}_{3}\right)_{2} \\
m / z 681(-60) \\
\mathrm{RA}=4 \%\end{array}$ \\
\hline & - & - & - & $\begin{array}{l}\mathrm{R}=\mathrm{CH}\left(\mathrm{CH}^{-}\right) \mathrm{CH}_{3} \\
m / z 666(-75) \\
\mathrm{RA}=5 \%\end{array}$ \\
\hline$<\mathrm{Cu}(\mathrm{I})>-$ & $\begin{array}{l}m / z 626(-87) \\
R A=30 \%\end{array}$ & $\begin{array}{l}m / z 626(-101) \\
R A=13 \%\end{array}$ & $\begin{array}{l}m / z 626(-115) \\
R A=14 \%\end{array}$ & $\begin{array}{l}m / z 626(-115) \\
R A=8 \%\end{array}$ \\
\hline$<\mathrm{Cu}(\mathrm{II})>=\mathrm{N}$ & $\begin{array}{l}m / z 611(-102) \\
R A=45 \%\end{array}$ & $\begin{array}{l}m / z 611(-116) \\
R A=5 \%\end{array}$ & $\begin{array}{l}m / z 611(-130) \\
R A=8 \%\end{array}$ & $\begin{array}{l}m / z 611(-130) \\
R A=17 \%\end{array}$ \\
\hline
\end{tabular}

bilizes high-valent transition-metal centers. Corroles were also proposed as MALDI matrices because of their low ionization potential along with their high UV absorption [36]. Lately, the fragmentation of meso-pentafluorophenyl-corrole has been reported [37].

To develop a metallocorrole-based derivatization method, for the induction of radical processes, it is initially necessary to study the dissociation reactions in amino acids. However, to bind amino acids to corroles, a reactive spacer has to be introduced as, evidently, corrole carboxaldehyde does not react with free amino acids. Thus, the purpose of the present work is to exploit metallocorroles as charge derivatives for the initiation of homolytic cleavages in amino acid esters. One of the characteristics of corroles and metallocorroles is their high tendency to generate anions by electron capture in the MALDI and ESI sources. It is therefore possible to study the CID of these negatively charged ions that are highly abundant. Hence, in this work we prepared and studied the negatively charged anions of amino acid esters that are covalently bound to copper corrole. 
Table 2. Summary and interpretation of CID fragments produced from $[(\mathrm{Cu}) \mathrm{TrpOMe}]^{-*},[(\mathrm{Cu}) \mathrm{TyrOMe}]^{-\cdot}$ and $[(\mathrm{Cu}) \mathrm{PheOMe}]^{-}$

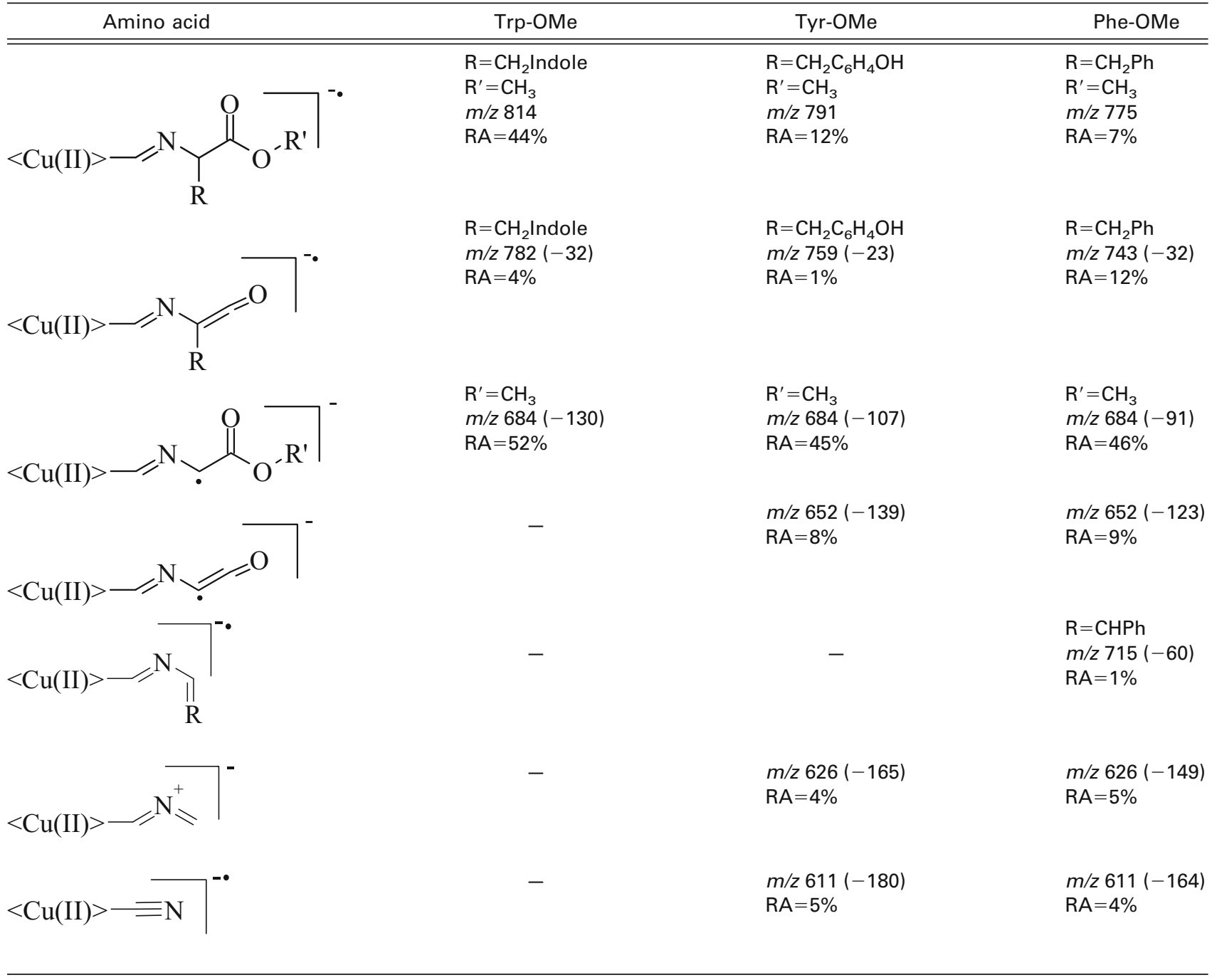

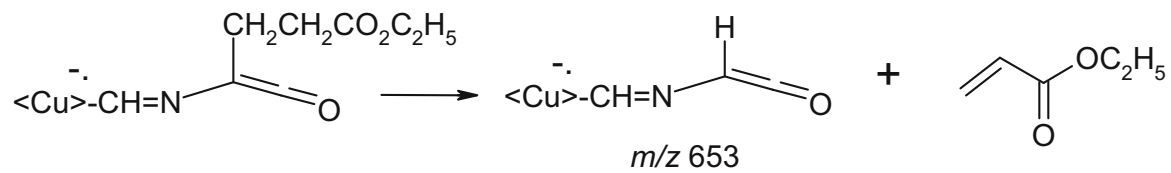<smiles>CC(C)(C)[Ge]=C=NC(=O)Cc1c[nH]cn1</smiles>

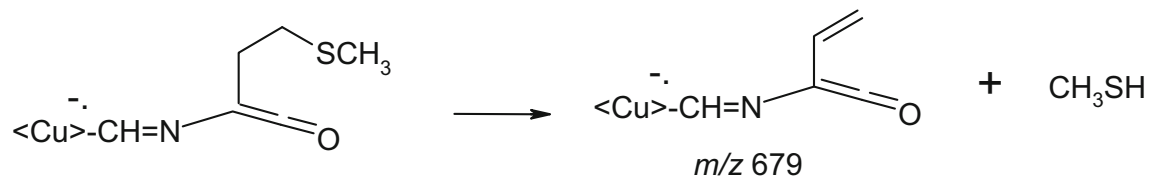

Scheme 3. Initial loss of alcohol from the ester, followed by side chain cleavages with the elimination of closed shell neutrals. 


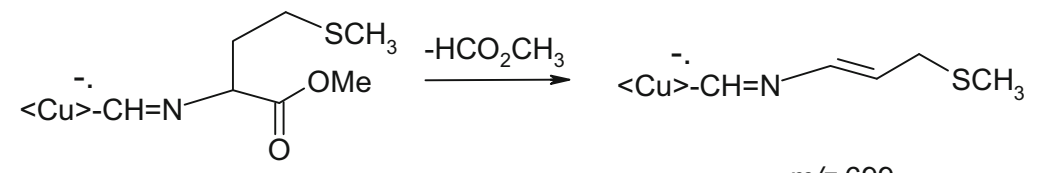

$m / z 759$

$m / z 699$

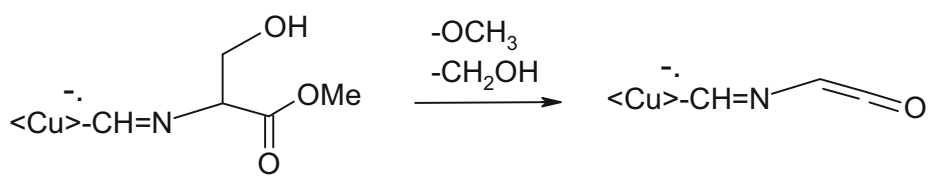

$m / z 759$

$m / z 653(100 \%)$

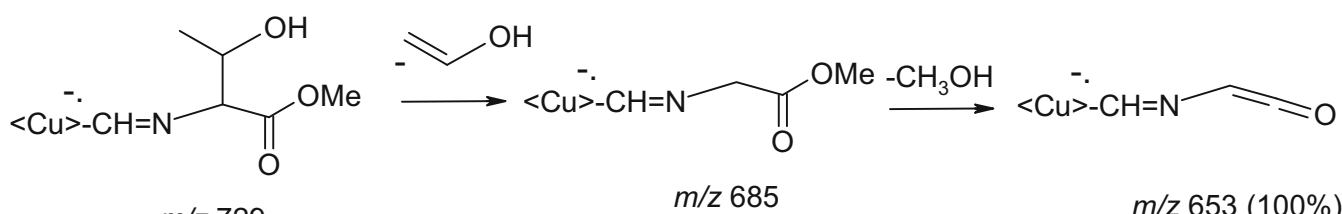

Scheme 4. Side chain cleavages that result in the formation of anion radicals.

Table 3. Summary and interpretation of CID fragments produced from $[(\mathrm{Cu}) \text { SerOMe }]^{-*},[(\mathrm{Cu}) \mathrm{ThrOMe}]^{-*},\left[(\mathrm{Cu}) \mathrm{Glu}(\mathrm{OEt})_{2}\right]^{-*}$, $[(\mathrm{Cu}) \mathrm{HisOMe}]^{-\cdot}$ and $[(\mathrm{Cu}) \mathrm{MetOMe}]^{-\cdot}$

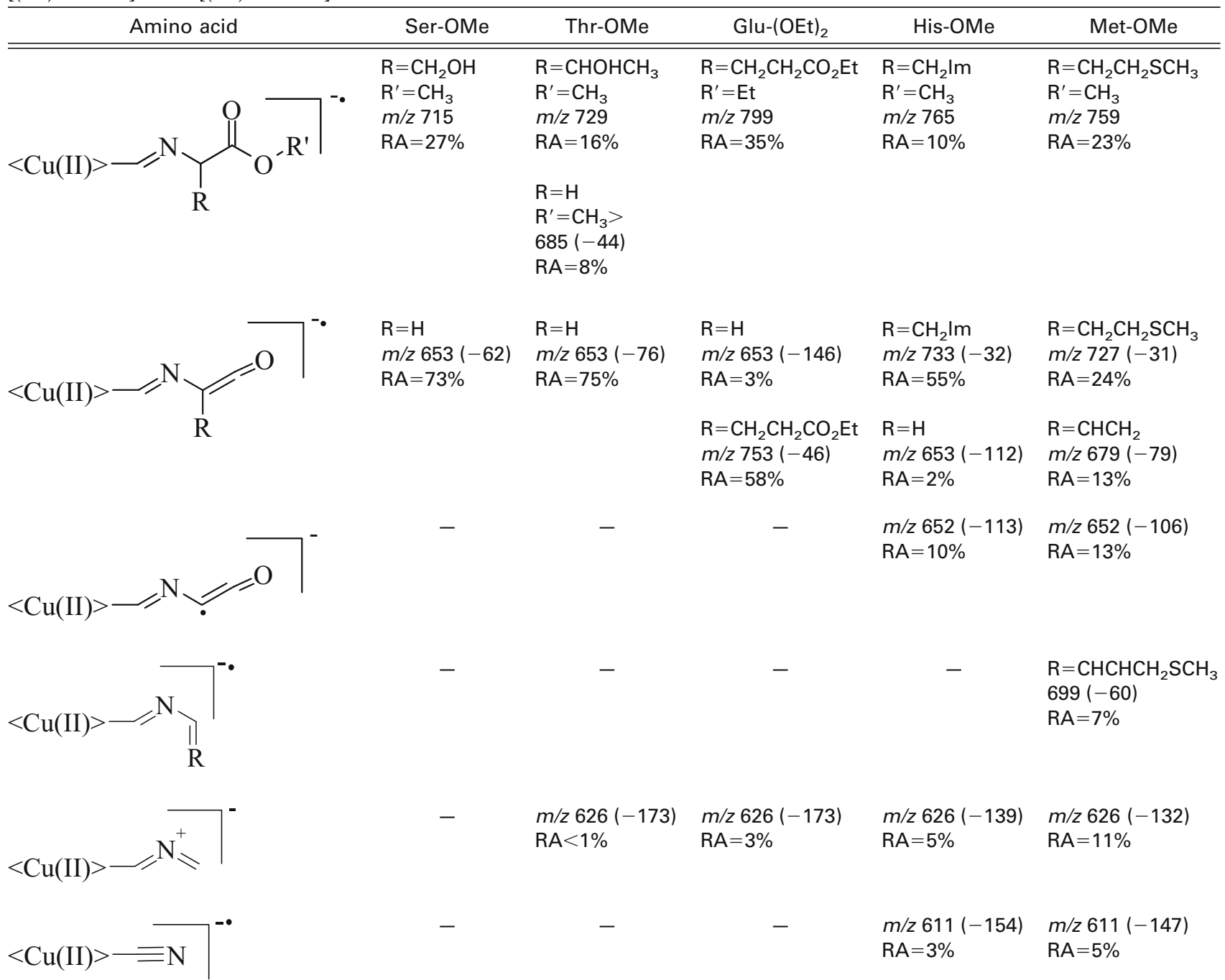




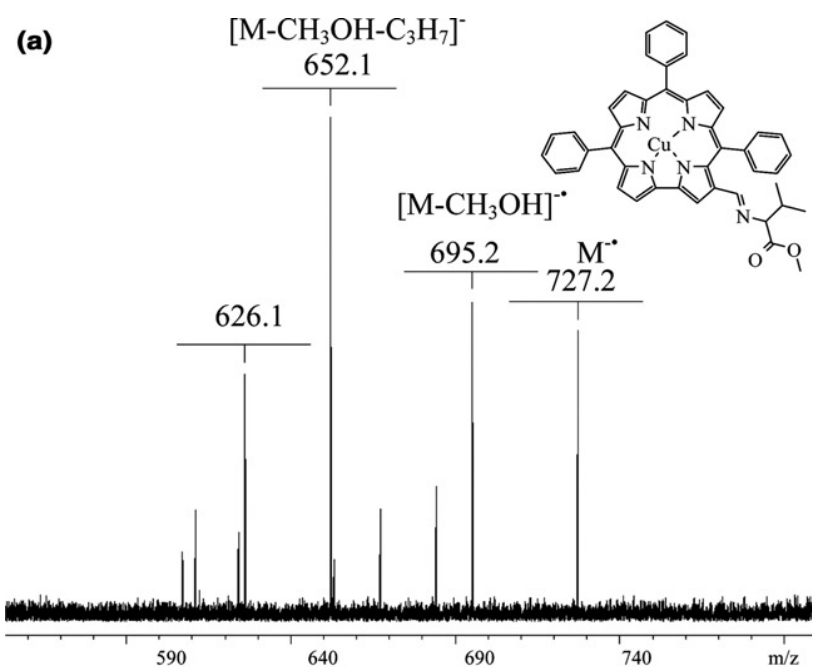

(b)
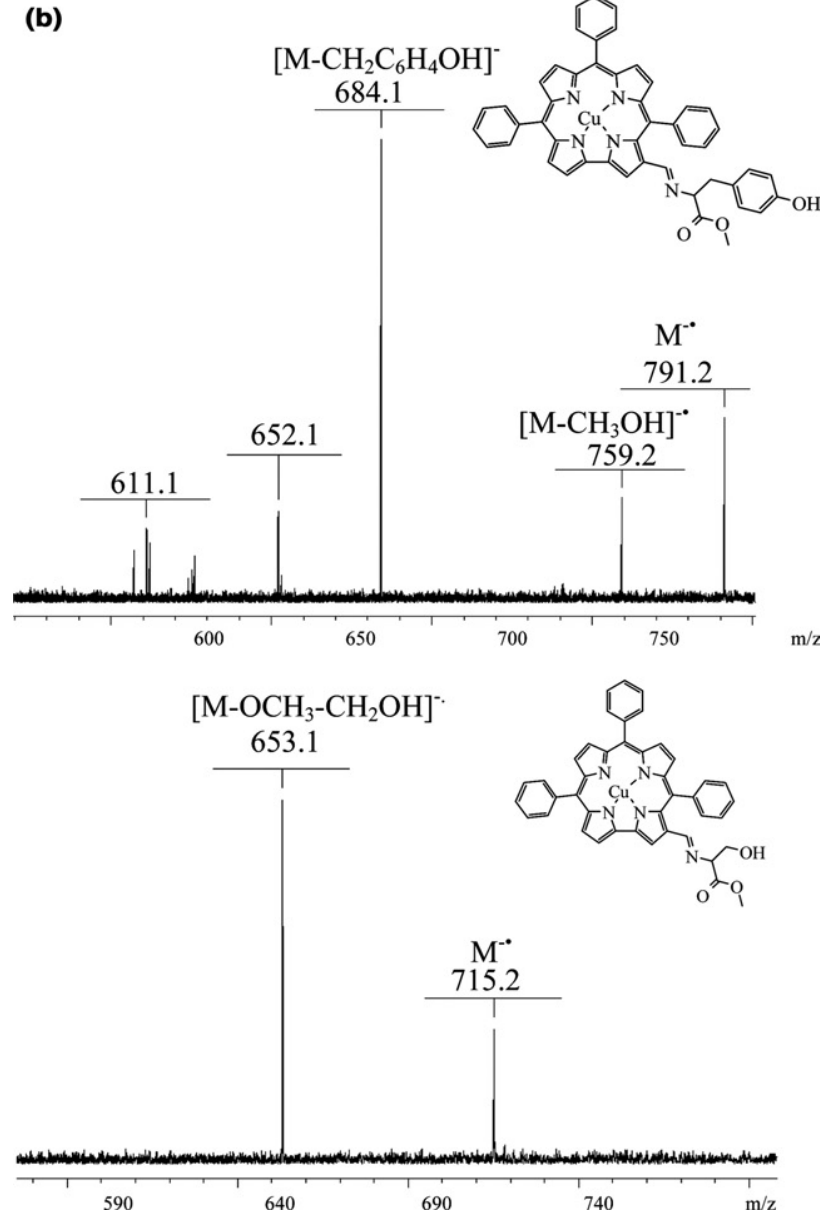

Figure 2. The CID spectra that were measured for the anion radicals of ValOMe (a), TyrOMe (b) and ThrOMe (c) with FT-ICR.

\section{Experimental}

\section{Synthesis}

Chemical were purchased from Sigma-Aldrich and used without purification. Trisphenylcorrole was synthesized according to literature procedure [38 $\left.{ }^{\mathrm{a}}\right]$. Formylation $\left[38^{\mathrm{b}}\right]$ of the corrole and insertion of copper [39] were also performed according to known procedure. Coupling of the formylated corrole- $\mathrm{Cu}$ complex to the amino acid esters was performed according to the following general procedure. The formylated corrole-Cu was dissolved in dry THF and appropriate amino acid ester was added. Minute amount of $\mathrm{Na}_{2} \mathrm{SO}_{4}$ was used as dehydration agent. When hydrochloride salts of amino acid esters were used, equivalent amount of ethyldiisopropyl amine was added. After stirring at ambient temperature over night the sample was diluted and injected into the electrospray without any purification.

\section{Mass spectrometry}

MALDI-TOF measurements were carried out with a MALDI micro MX (Waters/Mircomass, Manchester, England), without matrix. ESI/FTICR experiments were carried out using Bruker BioAPEX III 47e FTICR mass spectrometer (Bruker Analytical Systems, Inc., Billerica, MA) equipped with a $4.7 \mathrm{~T}$ superconducting magnet, an external source (Apollo ESI Source), and an infinity analyzer cell. The samples were dissolved in 1:1 volume ratio of $\mathrm{CH}_{3} \mathrm{OH} / \mathrm{CH}_{3} \mathrm{CN} 0.01 \mathrm{mg} / \mathrm{ml}$ and introduced into the ESI source at a flow rate of $0.3 \mu \mathrm{l}$ $\min ^{-1}$. The trapped ions were resonantly excited using a swept frequency RF “chirp". Ions were detected using the broadband detection mode covering a mass range from 100 to $3000 \mathrm{u}$. Typically, 16 individual transients were accumulated to improve the signal-to-noise ratio. Precursor ions were isolated using swept frequency ejection pulses of ca. $250 \mu$ s duration to eject all other ions. A pulsed valve introduced the argon collision gas before ion activation. With the pulsed valve open for 10 ms a peak pressure of $\sim \exp -7$ mbar was obtained. The precursor ions were excited using a variable amplitude off-resonance excitation pulse. CID measurements for leucine, isoleucine, and peptides complexes were recorded using an $\mathrm{LCQ}_{\mathrm{DUO}}$ ion trap instrument (ThermoFinnigan, San Jose, CA) with ESI and APCI interfaces. The samples were dissolved in acetonitrile $(1.0 \mathrm{mg}$ in $100 \mathrm{~mL}$ ) and introduced into the ESI source at a flow rate of $0.5 \mathrm{~mL} \mathrm{~h}^{-1}$. Isolation of precursor ions for MS/MS was accomplished with a window of $3 \mathrm{u}$. Helium was used as collision gas at 17 to $19 \%$ energy, so that parent ions could still be detected.

\section{Results and Discussion}

As a first step, a series of metallocorroles were prepared and analyzed by mass spectrometry, to learn about their oxidation states and relative stability. Triphenylcorrole 1 was prepared according to known procedures [38], and the corresponding metallocorroles are also known [39]. The resulting complexes were mass measured with the aid of a MALDI-TOF instrument without matrix (see Supplementary Material section, which can be found in the electronic version of this article). It is found that these compounds are better analyzed in the nega- 


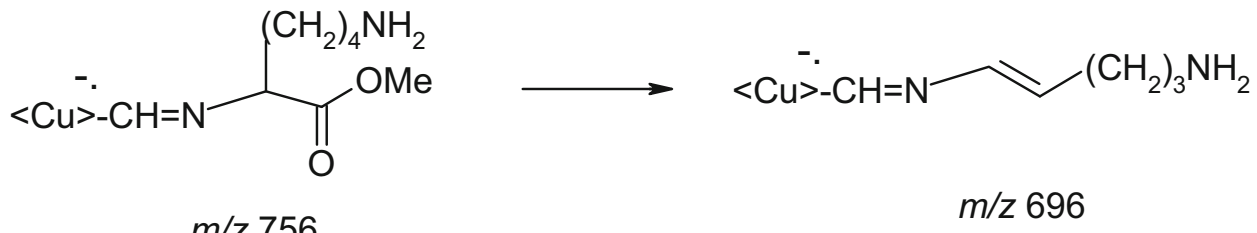

Scheme 5. Methyl carboxylate cleaved off without any side chain fragmentations.

tive mode, however, Figure 1 depicts mass spectra that were measured for the copper complex with MALDI and ESI, both in positive and negative mode. The measured masses indicate the formation of radical ions, as expected (the metallocorrole moiety is designated in brackets around the metal, $<\mathrm{M}>$ ). Complexes with $\mathrm{Fe}$, $\mathrm{Mn}, \mathrm{Co}, \mathrm{Ni}, \mathrm{Cr}, \mathrm{Pd}, \mathrm{Ag}$ and $\mathrm{Cu}$ were prepared and mass measured showing that cation and anion radicals are generated in all of the metallocorrole complexes upon MALDI or ESI ionization (with lower sensitivity).

Since a charge derivatization reagent must be stable upon collisional activation, CID experiments were conducted for all of the above listed metallocorroles (see Supplementary material). Some of the complexes show extensive loss of benzene (i.e., $\langle\mathrm{Fe}\rangle$,
$<\mathrm{Co}\rangle,\langle\mathrm{Pd}>$ ) and others lose the metal (i.e., $\mathrm{Ag}$ ). Evidently, the most stable ions are the negatively charged copper and nickel complexes. Due to synthetic limitations, only the copper complex $<\mathrm{Cu}\rangle$ was used further on. Obviously $\langle\mathrm{Cu}\rangle$ is a $\mathrm{d}^{8} \mathrm{com}-$ plex that upon electron capture becomes an openshell $\mathrm{d}^{9}$ species. This is required to initiate homolytic processes. Copper was inserted to the formylated corrole, forming the complex $<\mathrm{Cu}>\mathrm{CHO}$ [39] that reacts at the $\mathrm{N}$-terminus of the analyzed amino acid esters (AA) or peptides by a simple chemical process (Scheme 1).

Derivatization was applied on a variety of amino acid esters, affording complexes that are easily ionized into stable radical anions (Scheme 1) upon electrospray

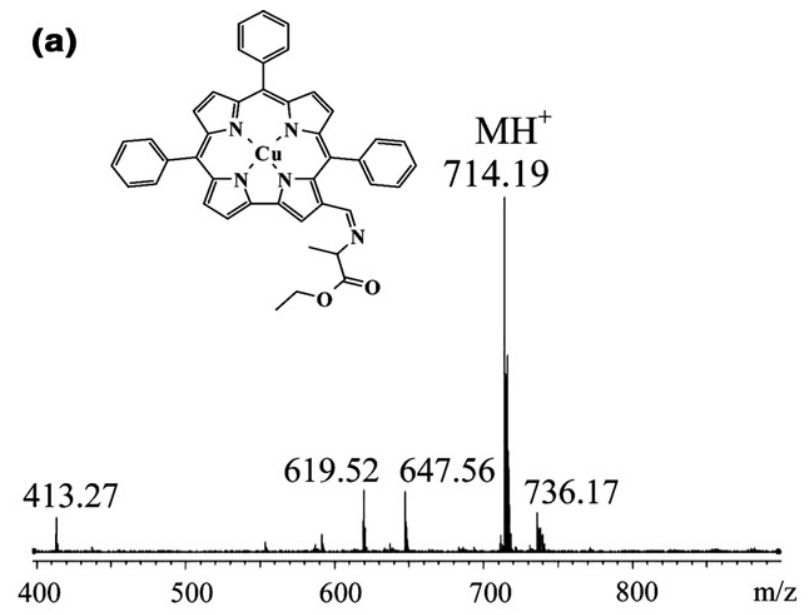

\section{(c)}

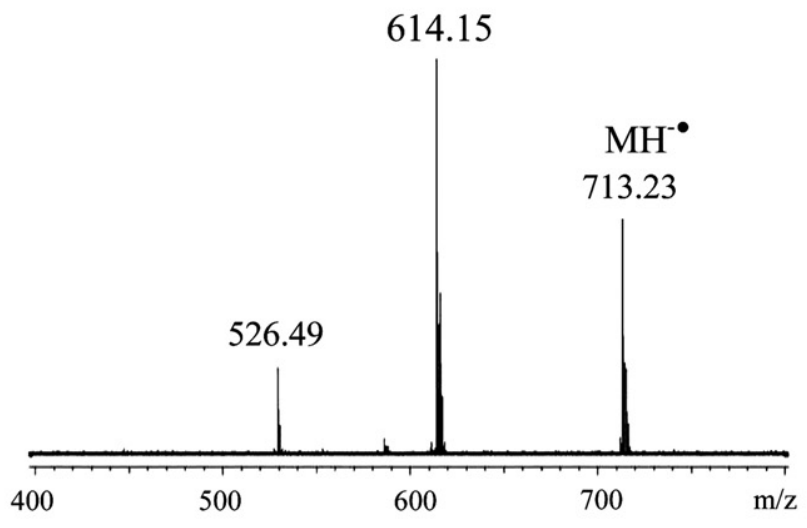

(b)

(d)
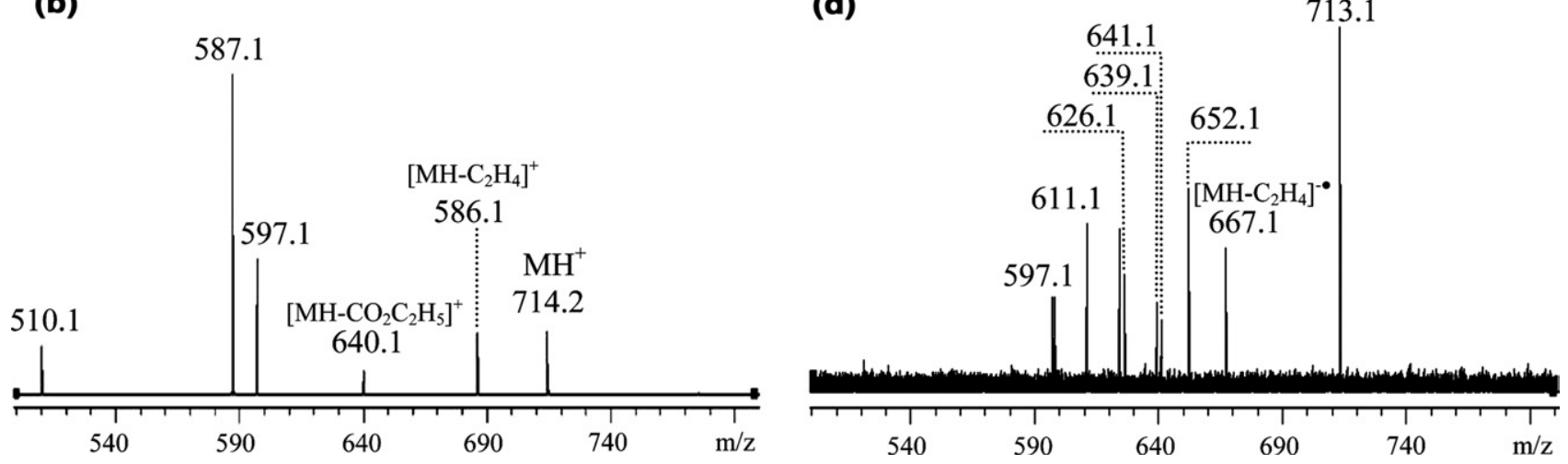

Figure 3. MS and CID spectra of AlaOEt under positive and negative ESI spectra (a) $<\mathrm{Cu}>\mathrm{AlaOEt}$, positive mode, (b) CID of $[<\mathrm{Cu}>\text { AlaOEt }+\mathrm{H}]^{+}(\mathrm{m} / \mathrm{z} 714.2)$, measured with an FT-ICR, (c) $<\mathrm{Cu}>$ AlaOEt, negative mode, $(\mathbf{d}) \mathrm{CID}$ of $\left[<\mathrm{Cu}>\mathrm{AlaOEt}^{-\cdot}(\mathrm{m} / \mathrm{z} 713.2)\right.$, measured with an FT-ICR. 
(a)

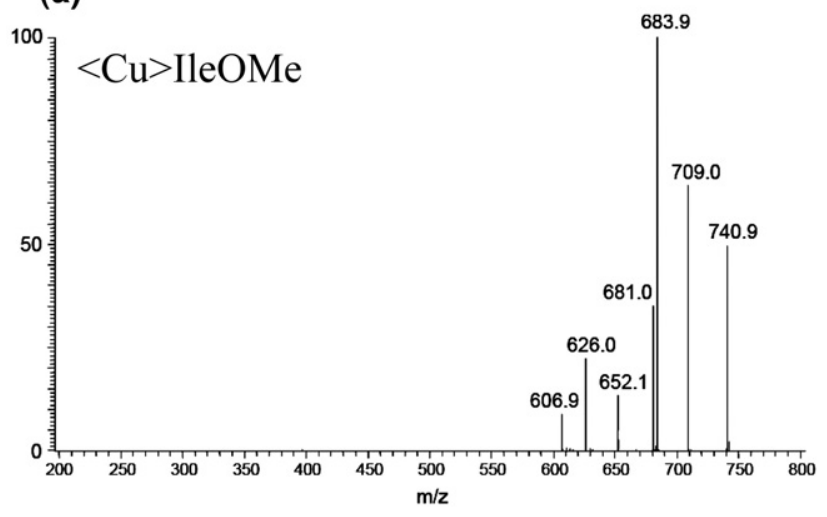

(b)

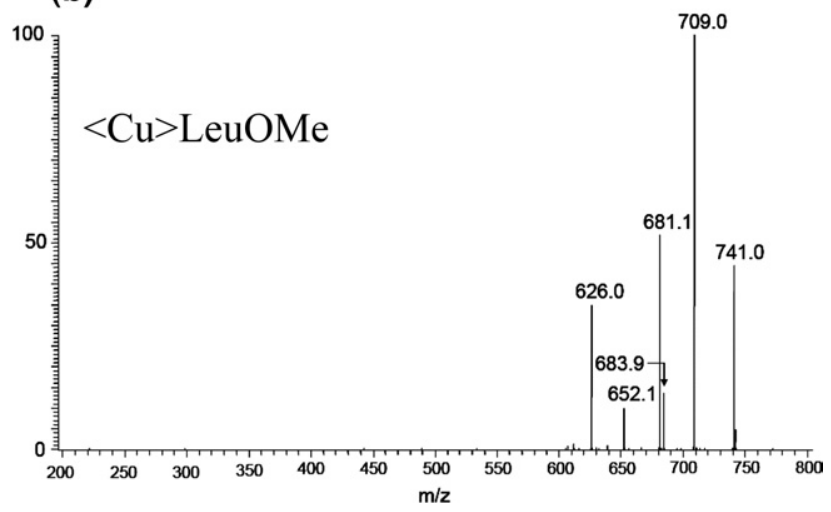

Figure 4. CID spectra of $<\mathrm{Cu}>$ Ile (a) and $<\mathrm{Cu}>$ Leu (b), measured with an LCQ ion trap.

or MALDI ionization. The derivatized amino acids were collisionally induced to dissociate with argon or helium (depending on the instrument) affording a series of fragments, some of which indicate cleavages at the alpha carbon with the involvement of the alkyl side chain, as desired.

As the compounds under study are amino acid esters, an abundant ion in each CID spectrum of the various anion radicals of $<\mathrm{Cu}>\mathrm{AAOR}$ corresponds to the elimination of methanol or ethanol from the alkyl carboxylate moiety (in some cases elimination of ethylene is observed). The various $<\mathrm{Cu}>\mathrm{AAOR}$ anion radicals can be divided into two groups, those which lose a radical moiety, affording a closed-shell product ion (Scheme 2, Table 1, and Table 2) and others that eliminate a closed-shell neutral, affording radical product ions (Scheme 3, Scheme 4, Table 3). The first group includes complexes for which AA is alanine, histidine, leucine, and isoleucine, phenylalanine, methionine, tyrosine, and valine. An example is presented in Figure 2 that illustrates the CID spectra that were measured for the anion radicals of $<\mathrm{Cu}>\mathrm{ValOMe},<\mathrm{Cu}>\mathrm{TyrOMe}$ and $<\mathrm{Cu}>$ ThrOMe.

Typically, an initial loss of $\mathrm{ROH}$ from the ester group is followed by homolytic cleavage at the alpha carbon, as depicted in Scheme 2 (see also Table 1 and Table 2). In some cases, homolytic cleavage at the alpha carbon occurs in the initial $<\mathrm{Cu}>\mathrm{AAOR}$ anion radical (i.e., $\mathrm{AA}=\mathrm{Trp}$, Ile, Phe, Tyr).

The results shown above indicate that homolytic cleavages occur in the metallocorroles under study, producing closed-shell products or anion radicals that are formed by two sequential radical losses. Nevertheless, the final product ions and neutrals are the ones that are more stable and in some cases these are products of two radical losses, giving rise to an anion radical product. Thus, $<\mathrm{Cu}>\mathrm{Glu}(\mathrm{OEt})_{2}$, $<\mathrm{Cu}>$ HisOMe and $<\mathrm{Cu}>$ MetOMe undergo elimination of alcohol from the ester followed by cleavage at the alpha carbon that result in the loss of neutral molecules, not radicals (Scheme 3, Table 2).

Other ions indicate the loss of closed-shell neutrals directly from the parent ion. This occurs in the CID spectrum of $<\mathrm{Cu}>$ MetOMe and to a larger extent in the CID spectra of $<\mathrm{Cu}>$ SerOMe and $<\mathrm{Cu}>$ ThrOMe. These processes are depicted in Scheme 4 and Table 3, while the $\mathrm{CID}$ spectrum that was measured for the anion radical of $<\mathrm{Cu}>$ SerOMe appears in Figure 2.

Among the amino acid esters that were studied here, only derivatized lysine does not afford informative side-chain fragmentations. Instead, it eliminates methylformate, as illustrated in Scheme 5.

The derivatized amino acids were also protonated and investigated by positive electrospray, however, side-chain fragmentation of protonated derivatized peptides is negligible, while facile informative fragmentation is observed at the negative mode.

Figure 3 shows the positive and negative ESI spectra of $<\mathrm{Cu}>$ AlaOEt and the CID spectra of the resulting $[<\mathrm{Cu}>\mathrm{AlaOEt}]^{-\cdot}$ And $[<\mathrm{Cu}>\mathrm{AlaOEt}+$ $\mathrm{H}^{+}$parent ions. It illustrates that in the positive mode a closed shell ion is formed while radicals are generated only upon negative mode ionization. It should also be added that the derivatized corrole (without metal) also affords closed shell ions, exclusively. Moreover, CID of negatively charged $[\mathrm{M}-\mathrm{H}]^{-}$ ions of amino acids and peptides do not cleave off side-chain groups $[40,41]$.

\section{Leucine and Isoleucine}

One of the advantages of radical initiated cleavages is the possible distinction between the isomeric leucine and isoleucine amino acids. Attempts to develop method of mass spectral determination of Leu and Ile that appear in literature involve both closed-shell [42, 43] and radical [26, 44-46] processes. However, the most valuable technique is shown by ECD and CID $[17,18]$, with the distinctive losses of $\mathrm{C}_{3} \mathrm{H}_{7}$ and $\mathrm{C}_{2} \mathrm{H}_{5}$ for Leu and Ile, respectively. This is nonetheless a minor peak of low abundance. Here it was also desired to find a distinctive differentiation between the two isomeric amino acids. Indeed, CID spectra of $<\mathrm{Cu}>$ Leu and $<\mathrm{Cu}>$ Ile that were recorded with an FT-ICR show an abundant $\left[\mathrm{M}-\mathrm{CH}_{3} \mathrm{OH}-\mathrm{C}_{3} \mathrm{H}_{7}\right]^{-}$ion only in the spectrum of the former $(\mathrm{m} / \mathrm{z}$ 666.1, see Supplementary material). 

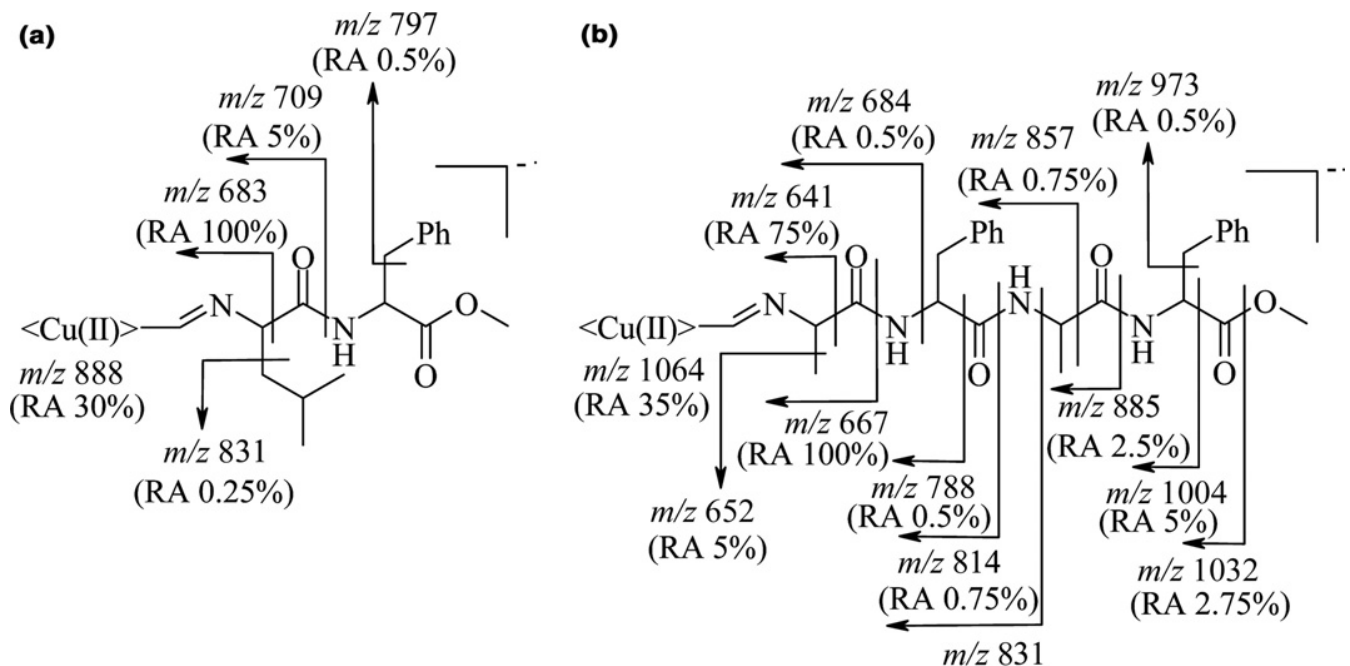

(RA $0.1 \%$ )

Figure 5. Fragmentation pathways of $(\mathbf{a})[<\mathrm{Cu}>\mathrm{LFOMe}]^{-\cdot}$ and (b) $[<\mathrm{Cu}>\mathrm{AFAFOMe}]^{-\cdot}$ upon CID (LCQ ion trap).

Since the differences are too small for clear identification, measurements were repeated with an LCQ ion trap as shown in Figure 4. There is no indication of ethyl loss in the two spectra. However, fragmentation at the alpha carbon, giving rise to a $\left[\mathrm{M}-\mathrm{C}_{4} \mathrm{H}_{9}\right]^{-}$ion of $m / z 684$ is significantly more pronounced in the CID spectrum of Ile. Thus, the $\left[\mathrm{M}-\mathrm{C}_{4} \mathrm{H}_{9}\right]^{-} / \mathrm{M}^{-\cdot}$ ion ratio in the two spectra are 3 and 0.5 for $<\mathrm{Cu}>$ Leu and $<\mathrm{Cu}>$ Ile, respectively. Figure 5.

\section{Peptides}

A preliminary attempt to connect $C$-protected short peptides to $<\mathrm{Cu}>\mathrm{CHO}$ shows that homolytic cleavages can be initiated, at least in the case of the di- and tetra-peptides shown below. Thus, Scheme 5 (see also Supplemental materials) summarizes the observed cleavages in the CID spectra of corresponding $\left[<\mathrm{Cu}>\mathrm{LFOMe}^{-\cdot}\right.$ and $\left[<\mathrm{Cu}>\mathrm{AFAFOMe}^{-\cdot}\right.$ ions. Clearly, favored cleavage occurs by the $<\mathrm{Cu}>$ moiety, while fragmentation remote to this group is less abundant. It is expected that the induction of homolytic cleavages along the peptides, remote to the metallocorrole, will be enhanced in the presence of a saturated spacer between the corrole moiety and the peptide [47]. This requires additional synthetic method development; however, it is already shown that $\alpha$-cleavages occur also in the case of these di- and tetra-peptides.

\section{Conclusions}

It has been shown that the special redox properties of corroles can be exploited for the generation of radicals in amino acid esters and small peptides. This results in informative fragmentations in the sidechain moieties at the alpha carbon, as desired. The different processes result in the formation of anion and radical anion products. Electron capture dissociation induces the cleavages of $\mathrm{N}-\mathrm{C}_{\alpha}$ bonds after carbonyl hydrogen abstraction. Here, the active species may be an anion radical at the carbonyl that cleaves off the $\mathrm{R}-\mathrm{C}_{\alpha}$ alkyl chain. Alternatively, the electron may be localized at the corrole backbone. Further study is needed to present a detailed mechanistic description. Presently, more peptide radicals are generated with the same method.

\section{Acknowledgments}

The authors are thankful to Mr. Alexander Tsoglin for his help with producing the CID spectra that were recorded on an LCQ ion trap.

\section{References}

1. Steen, H.; Mann, M. The abc's (and xyz's) of Peptide Sequencing. Nature Rev 2004, 5, 699-711.

2. Lill, J. Proteomic Tools for Quantitation by Mass Spectrometry. Mass Spectrom. Rev. 2003, 22, 182-194.

3. Hamdan, M.; Righetti, P. G. Modern Strategies for Protein Quantification in Proteome Analysis: Advantages and Limitations. Mass Spectrom. Rev. 2002, 21, 287-302.

4. Yates, J. R. Mass Spectrometry and the Age of the Proteome. J. Mass Spectrom. 1998, 33, 1-19.

5. Hart, S. R.; Gaskell, S. J. LC-Tandem MS in Proteome Characterization. Trends Anal. Chem. 2005, 24, 566-575.

6. Wysocki, V. H.; Resing, K. A.; Zhang, Q.; Cheng, G. Mass Spectrometry of Peptides and Proteins. Methods 2005, 35, 211-222.

7. Bogdanov B.; Smith, R. D.; Proteomics by FTICR Mass Spectrometry: Top Down and Bottom up. Mass Spectrom. Rev. 2005, 24, 168-200 and references therein.

8. Zubarev, R. A. Reactions of Polypeptide Ions with Electrons in the Gas Phase. Mass Spectrom. Rev. 2003, 22, 57-77.

9. Roth, K. D. W.; Huang, Z.-H.; Sadagopan, N.; Watson, J. The Charge Derivatization of Peptides for Analysis by Mass Spectrometry. Mass Spectrom. Rev. 1998, 17, 255-274.

10. Sadagopan, N.; Watson, J. T. Mass Spectrometric Evidence for Mechanisms of Fragmentation of Charge-Derivatized Peptides. J. Am. Soc. Mass Spectrom. 2001, 12, 399-409.

11. Nachman, R. J.; Russell, W. K.; Coast, G. M.; Russell, D. H.; Prede, R. Mass Spectrometric Assignment of Leu/Ile in Neuropeptides from Single Neurohemal Organ Preparations of Insects. Peptides 2005, 26 , 2151-2156. 
12. Guan, J.-Q.; Chance, M. R. Structural Proteomics of Macromolecular Assemblies Using Oxidative Footprinting and Mass Spectrometry. Trends Biochem. Sci. 2005, 30, 583-592.

13. Zubarev, R. A.; Horn, D. M.; Fridriksson, E. K.; Kelleher, N. L.; Kruger, N. A.; Lewis, M. A.; Carpenter, B. K.; McLafferty, F. W. Electron Capture Dissociation for Structural Characterization of Multiply Charged Protein Cations. Anal. Chem. 2000, 72, 563-573.

14. Tsybin, Y. O.; Ramstroem, M.; Witt, M.; Baykut, G.; Hakansson, P. Peptide and Protein Characterization by High-Rate Electron Capture Dissociation Fourier Transform Ion Cyclotron Resonance Mass Spectrometry. J. Mass Spectrom. 2004, 39, 719-729.

15. Kruger, N. A.; Zubarev, R. A.; Horn, D. M.; McLafferty, F. W. Electron Capture Dissociation of Multiply Charged Peptide Cations. Int. J. Mass Spectrom. 1999, 185/186/187, 787-793.

16. Cooper, H. J.; Hakansson, K.; Marshall, A. G. The Role of Electron Capture Dissociation in Biomolecular Analysis. Mass Spectrom. Rev. 2005, 24, 201-222.

17. Cooper, H. J.; Hudgins, R. R.; Hakansson, K.; Marshall, A. G. Characterization of Amino Acid Side-Chain Losses in Electron Capture Dissociation. J. Am. Soc. Mass Spectrom. 2002, 13, 241-249.

18. Kjeldsen, F.; Haselmann, K. F.; Sørensen, E. S.; Zubarev, R. A. Distinguishing of Ile/Leu Amino Acid Residues in the PP3 Protein by (Hot) Electron Capture Dissociation in Fourier Transform Ion Cyclotron Resonance Mass Spectrometry. Anal. Chem. 2003, 75, 1267-1274.

19. Zubarev, R. A.; Kelleher, N. L.; McLafferty, F. W. Electron Capture Dissociation of Multiply Charged Protein Cations. A Nonergodic Process. J. Am. Chem. Soc. 1998, 120, 3265-3266.

20. Barlow, C. K.; Wee, S.; McFadyen, W. D.; O'Hair, R. A. Designing Copper(II) Ternary Complexes to Generate Radical Cations of Peptides in the Gas Phase: Role of the Auxiliary Ligand. Dalton Trans. 2004, 20, 3199-3204.

21. Wee, S.; O'Hair, R. A. J.; McFadyen, W. D. Comparing the Gas-Phase Fragmentation Reactions of Protonated and Radical Cations of the Tripeptides GXR. Int. J. Mass Spectrom. 2004, 234, 101-122.

22. Bagheri-Majdi, E.; Ke, Y.; Orlova, G.; Chu, I. K.; Hopkinson, A. C.; Siu, K. W. M. Copper-Mediated Peptide Radical Ions in the Gas Phase. J. Phys. Chem. B 2004, 108, 11170-11181.

23. (a)Chu, I. K.; Rodriquez, C. F.; Lau, T.-C.; Hopkinson, A. C.; Siu, K. W. M. Molecular Radical Cations of Oligopeptides. J. Phys. Chem. B 2000, 104, 3393-3397; (b) Chu, I. K.; Siu, S. O.; Lam, C. N. W.; Chan, J. C. Y.; Rodriquez, C. F. Formation of molecular radical cations of aliphatic tripeptides from their complexes with CuII(12-crown-4). Rapid Commun. Mass Spectrom. 2004, 18, 1798-1802.

24. Gatlin, C. L.; Turecek, F.; Vaisar, T. Copper(II) Amino Acid Complexes in the Gas Phase. J. Am. Chem. Soc. 1995, 117, 3637-3638.

25. Chu, I. K.; Siu, S. O.; Lam, C. N. W.; Chan, J. C. Y.; Rodriquez, C. F. Formation of Molecular Radical Cations of Aliphatic Tripeptides from Their Complexes with CuII(12-Crown-4). Rapid Commun. Mass Spectrom. 2004, 18, 1798-1802.

26. Vaisar, T.; Gatlin, C. L.; Turecek, F. Metal-Ligand Redox Reactions in Gas-Phase Quaternary Peptide-Metal Complexes by Electrospray Ionization Mass Spectrometry. Int. J. Mass Spectrom. Ion Processes 1997, 162, 77-87

27. Vaisar, T.; Gatlin, C. L.; Rao, R. D.; Seymour, J. L.; Turecek, F. Sequence Information, Distinction, and Quantitation of C-Terminal Leucine and Isoleucine in Ternary Complexes of Tripeptides with $\mathrm{Cu}(\mathrm{II})$ and 2,2'Bipyridine. J. Mass Spectrom. 2001, 36, 306-316.

28. Wee, S.; O'Hair, R. A. J.; McFadyen, W. D. Comparing the Gas-Phase Fragmentation Reactions of Protonated and Radical Cations of the Tripeptides GXR. Int. J. Mass Spectrom. 2004, 234(1/3), 101-122.

29. Wee, S.; O'Hair, R. A. J.; McFadyen, W. D. Side-Chain Radical Losses from Radical Cations Allows Distinction of Leucine and Isoleucine Residues in the Isomeric Peptides Gly-XXX-Arg. Rapid Commun. Mass Spectrom. 2002, 16, 884-890.

30. Hu, P.; Gross, M. L. Gas-Phase Interactions of Transition-Metal Ions and Di- and Tripeptides: A Comparison with Alkaline-Earth-Metal-Ion Interactions. J. Am. Chem. Soc. 1993, 115, 8821-8828.

31. Zhang J.; Brodbelt, J. S. Structural Characterization and Isomer Differentiation of Chalcones by Electrospray Ionization Tandem Mass Spectrometry. J. Mass Spectrom. 2003, 38, 555-572.

32. Barlow, C. K.; McFadyen, W. D.; O'Hair, R. A. J. Gas-Phase Ion Chemistry of Biomolecules. Part 44. Formation of Cationic Peptide
Radicals by Gas-Phase Redox Reactions with Trivalent Chromium, Manganese, Iron, and Cobalt Complexes. J. Am. Chem. Soc. 2005, 127 $6109-6115$.

33. Ito, A.; Okamura, T.; Yamamoto, H.; Ueyama, N.; Ake, K.; Masui, R.; Kuramitsu, S.; Tsunasawa, S. Distinction of Leu and Ile Using a Ruthenium(II) Complex by MALDI-LIFT-TOF/TOF-MS Analysis. Anal. Chem. 2005, 77, 6618-6624.

34. Okamura, T.; Iwamura, T.; Ito, A.; Kaneko, M.; Yamaguchi, M.; Yamamoto, H.; Ueyama, N.; Kuyama, H.; Ando, E.; Norioka, S.; Nakazawa, T.; Masui, R.; Kuramitsu, S. Application of Bis(Terpyridine)Ruthenium(II) to N-Terminal Amino Acid Sequencing. Chem. Lett. 2005, 34, 332-333.

35. Hodyss, R.; Cox, H. A.; Beauchamp, J. L. Bioconjugates for Tunable Peptide Fragmentation: Free Radical Initiated Peptide Sequencing (FRIPS). J. Am. Chem. Soc. 2005, 127, 12436-12437.

36. Ayorinde, F. O.; Hambright, P.; Porter, T. N.; Keith, Q. L., Jr. Use of Meso-Tetrakis(Pentafluorophenyl)Porphyrin as a Matrix for Low Molecular Weight Alkylphenol Ethoxylates in Laser Desorption/Ionization Time-of-Flight Mass Spectrometry. Rapid Commun. Mass Spectrom. 1999, 13, 2474-2479.

37. Lau, K. S. F.; Sadilek, M.; Gouterman, M.; Khalil, G. E.; Brueckner, C. Observation of Phenyl-Fused Porphyrinoids During the ESI Mass Spectrometric Analysis of Meso-Pentafluorophenyl-Substituted Porphyrin and Corrole. J. Am. Soc. Mass Spectrom. 2006, 17, 1306-1314.

38. (a)Paolesse, R.; Nardis, S.; Sagone, F.; Khoury, R. G. Synthesis and Functionalization of Meso-Aryl-Substituted Corroles. J. Org. Chem.2001,66, 550-556. (b) Paolesse, R.; Mini, S.; Sagone, F.; Boschi, T.; Jaquinod, L.; Nurco, D. J.; Smith, K. M. 5,10,15-Triphenylcorrole: A Product from a Modified Rothemund Reaction. Chem. Commun. 1999,14, 1307-1308.

39. (a)Luobeznova, I.; Simkhovich, L.; Goldberg, I.; Gross, Z. Electronic Structures and Reactivities of Corrole-Copper Complexes. Eur. J. Inorg. Chem. 2004, 8, 1724-1732. (b) Wasbotten, I. H.; Wondimagegn, T. Ghosh, A. Electronic Absorption, Resonance, Raman, and Electrochemical Studies of Planar and Saddled. Copper(III) Meso-Triarylcorroles Highly Substituent-Sensitive Soret Bands as a Distinctive Feature of High-Valent Transition Metal Corroles. J. Am. Chem. Soc. 2002, 124 8104-8116.

40. Li, Z.; Yalcin, T.; Cassady, C. J. C-Terminal Amino Acid Residue Loss for Deprotonated Peptide Ions Containing Glutamic Acid, Aspartic Acid, or Serine Residues at the C-Terminus. J. Mass Spectrom. 2006, 41 939-949.

41. Piraud, M.; Vianey-Saban, C.; Petritis, K.; Elfakir, C.; Steghens, J.-P. Morla, A.; Bouchu, D. ESI-MS/MS Analysis of Underivatized Amino Acids: A New Tool for the Diagnosis of Inherited Disorders of Amino Acid Metabolism. Fragmentation Study of 79 Molecules of Biological Interest in Positive and Negative Ionization Mode. Rapid Commun. Mass Spectrom. 2003, 17, 1297-1311.

42. Krishna, P.; Prabhakar, S.; Vairamani, M. Differentiation of Derivatized Leucine and Isoleucine by Tandem Mass Spectrometry Under Liquid Secondary Ion Mass Spectral Conditions. Rapid Commun. Mass Spectrom. 1998, 12, 1429-1434.

43. Hulst, A. G.; Kientz, C. E. Differentiation Between the Isomeric Amino Acids Leucine and Isoleucine Using Low-Energy Collision-Induced Dissociation Tandem Mass Spectroscopy. J. Mass Spectrom. 1996, 31, $1188-1190$.

44. Bossee, A.; Fournier, F.: Tasseau, O.; Bellier, B.; Tabet, J.-C. Electrospray Mass Spectrometric Study of Anionic Complexes of Enkephalins with $\mathrm{Cu}(\mathrm{II})$ : Regioselective Distinction of Leu/Ile at the CTerminus Induced by Metal Reduction. Rapid Commun. Mass Spectrom. 2003, 17, 1229-1239.

45. Seymour, J. L.; Turecek, F. Distinction and Quantitation of LeucineIsoleucine Isomers and Lysine-Glutamine Isobars by Electrospray Ionization Tandem Mass Spectrometry (MSn, $n=2,3$ ) of Copper (II)Diimine Complexes. J. Mass Spectrom. 2000, 35, 566-571.

46. Wee, S.; O'Hair, R. A. J.; McFadyen, W. D. Side-Chain Radical Losse from Radical Cations Allows Distinction of Leucine and Isoleucine Residues in the Isomeric Peptides Gly-XXX-Arg. Rapid Commun. Mass Spectrom. 2002, 16, 884-890.

47. Denekamp, C.; Rabkin, E.; Tsoglin, A. A New Charge Derivatization Procedure for Peptide Sequencing. Org. Biomol. Chem. 2005, 3, 2503 2504. 